\title{
Remembering Jim Swon, Industry Pioneer
}

$\mathrm{M}$

any of you in the industry may have heard the name Jim Swon. Jim was the founder of VanKel Industries, one of the first manufacturers of dissolution equipment. Jim was intimately involved in every facet of the VanKel business, but dealing directly with customers was his favorite activity. The consummate salesman, Jim was truly the customer's advocate.

Jim expanded the VanKel organization well beyond the United States by opening offices in Latin America and Europe. A strong believer in long-term relationships, Jim developed not just business relationships, but personal friendships all over the globe. He was a big believer in giving back to the dissolution community. Whether it was through the University Program or through the Dissolution Discussion Group, he helped support the science of dissolution. After building VanKel into the market leader, Jim sold the business to Varian, Inc., in 2000. He was personally committed to making sure the transition went smoothly and worked for Varian for several years after the sale. In 2003, Jim left the business to focus his time on his family. Jim will be sorely missed by all who knew him.

Allan Little, Director of Marketing, Dissolution Systems, Agilent Technologies

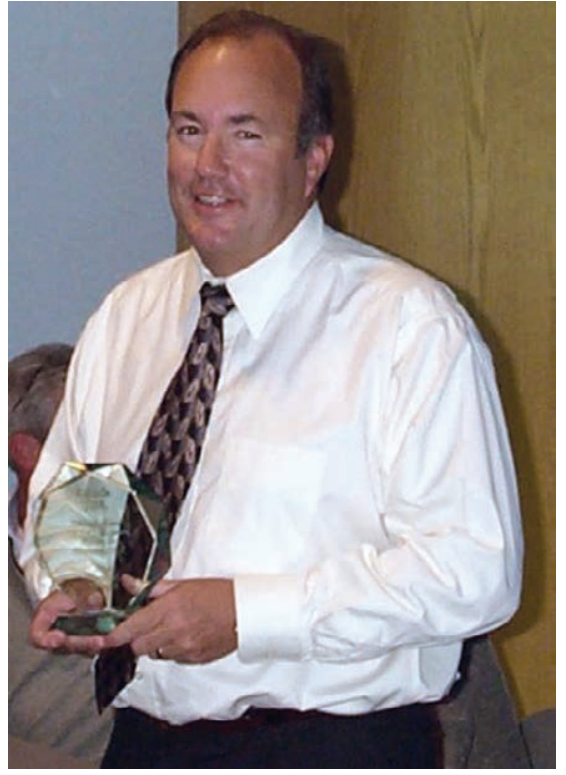

